DOI: https://doi.org/10.15688/lc.jvolsu.2018.1.12

UDC $341.1 / .8+342.7: 341.241$

LBC 67.022.155

\title{
TREATIES AS SOURCES OF PUBLIC LAW
}

\author{
Egor V. Krivosheev \\ Ural State Legal University, Ekaterinburg, Russian Federation
}

Introduction: the contractual form of regulating the relations which is specific for private law has recently been widely used for the registration of public relations. Despite this, today the place of treaties among the sources of public law is not clearly defined; therefore, the author sets the goal to study the treaty as a source of public law. Methods: the methodological framework for this study is a set of methods of scientific knowledge, among which the main are the methods of consistency, analysis and comparative law. Results: proved in the work the author's point of view is based on the legislation and of the competent academic community's opinions of the issue of the criteria of the treaty as a source of public law. The issues of legal impact on treaties, as well as the advantages of the treaty over other sources of public law are raised. Conclusions: the study revealed the need to develop a universal definition of the law treaty, to sufficiently study both the theory of the treaty and the theory of the legal act as a whole, as well as to publish the law on normative legal acts, which will include the relevant provisions.

Key words: law treaty, system of sources of law, public law, domestic treaties, international treaties.

УДК $341.1 / .8+342.7: 341.241$

ББК 67.022 .155

\section{ДОГОВОРЫ КАК ИСТОЧНИКИ ПУБЛИЧНОГО ПРАВА}

\section{Егор Вячеславович Кривошеев}

Уральский государственный юридический университет, г. Екатеринбург, Российская Федерация

Введение: договорная форма регулирования отношений, характерная для частного права, в последнее время получила широкое распространение и для оформления публичных отношений. Несмотря на это, место договоров среди источников публичного права на сегодняшний день однозначно не определено, в связи с чем автором в работе поставлена цель исследования договора как источника публичного права. Методы: методологическую основу данного исследования составляет совокупность методов научного познания, среди которых основное место занимают методы системности, анализа и сравнительно-правовой. Результаты: обоснованная в работе авторская позиция опирается на законодательство и мнения компетентной научной среды по вопросу о критериях договора как источника публичного права. Поднимаются вопросы правового воздействия на договоры, а также преимущества договора перед другими источниками публичного права. Выводы: в результате исследования выявлена необходимость выработать универсальное определение нормативного договора, в достаточной мере проработать как теорию договора, так и теорию правового акта в целом, а также издать закон о нормативных правовых актах, в который будут включены соответствующие положения.

Ключевые слова: нормативный договор, система источников права, публичное право, внутригосударственные договоры, международные договоры.

\section{Введение}

В российской правовой системе принято считать, что публичное право состоит из отраслей, связанных с полномочиями и функционированием государства, а именно: конституционного, международного публичного права, административного, уголовного, уголовно-процессуального, финансового. Однако деятельность государства может затрагивать и частноправовые сферы, например приватизацию государственного имущества или заключение внешнеэкономических сделок [6, с. 263]. Так, Правительство РФ при 
получении иностранных кредитов руководствуется международными договорами, гражданско-правовыми договорами от имени РФ или Правительства РФ.

Договорная форма регулирования отношений, характерная для частного права, в последнее время получила широкое распространение и для оформления публичных отношений. Несмотря на это, место договоров среди источников публичного права на сегодняшний день однозначно не определено.

Что касается самого понятия источника права, то представляется, что наиболее полным является определение В.Д. Перевалова, согласно которому источник права - это форма официального выражения общеобязательных предписаний, создаваемых органами государства в целях регламентации общественного порядка. Следует отметить, что общеобязательные предписания содержатся не только в нормативно-правовых актах, но и в нормативных договоpax, a также в иных источниках $[10$, с. 80]. Однако само понятие источника права может рассматриваться двояко: в качестве начала, откуда происходит само право, либо источника с уже сформированным в себе правилом. Последний представляет наибольший интерес для детального изучения [4, с. 80].

Исходя из этого, источники публичного права можно определить как нормативные юридически акты, регулирующие (закрепляющие) публичные отношения и содержащие нормы публичного права.

Главным источником права вообще и, в том числе, публичного права несомненно является Конституция РФ, которая закрепляет основные характеристики общества и государства, статуса личности. Кроме этого Конституция определяет систему и иерархию источников права в РФ (ст. 15, 71, 72, 76 Конституции РФ) [4, с. 82].

Конституцией РФ предусмотрены такие источники как: федеральные законы, федеральные конституционные законы, конституции и уставы субъектов федерации, международные договоры РФ, общепризнанные принципы и нормы международного права, законы и иные нормативно-правовые акты субъектов РФ, федеративные и иные договоры о разграничении предметов ведения и полномочий (ст. 11, 15, 76 Конституции РФ).
Что касается иерархии источников права, то Конституцией устанавливается ее приоритет, а также определяется верховенство международных договоров над законами (ст. 15 Конституции РФ).

\section{Понятие и виды договоров как источников права}

В качестве самостоятельного источника публичного права принято выделять договоры, которые можно группировать по разным критериям.

Есть несколько отличий договоров публичного права от частноправовых, одним из которых является субъект. В первом случае субъектами чаще всего выступают только некоммерческие организации (государство, его органы), а во втором случае - субъекты частного права (физические, юридические лица, коммерческие организации).

Кроме того, как и иные правовые акты, договоры могут быть нормативными и правоприменительными. И публично-правовые, и частноправовые договоры, в свою очередь, делятся на такие виды, как: 1) рассчитанные на неоднократную реализацию; 2) предназначенные для разового применения.

По численности участников различаются договоры: 1) индивидуализированные (с ограниченным, двусторонним участием) и 2) многосторонние (с широким числом участников) и др.

Важной среди классификаций является деление договоров на международные (межгосударственные договоры, договоры государства с международными организациями) и внутригосударственные (договоры между органами государственной власти РФ и органами государственной власти субъектов, договоры между субъектами федерации, договоры между субъектом и муниципальным образованием, межмуниципальные соглашения).

Несмотря на определенное Конституцией РФ 1993 г. место международных договоров в системе источников права, они занимают обособленное положение по отношению к национальной правовой системе, так как направлены на регулирование отношений субъектов, над которыми не существует единой высшей суверенной власти, и этими же субъектами со- 


\section{ТЕОРИЯ И ПРАКТИКА ГОСУДАРСТВЕННО-ПРАВОВОГО РАЗВИТИЯ}

здаются, а внутригосударственные договоры создаются субъектами правотворчества, имеющими единую государственную принадлежность, и составляющими единую иерархическую систему правовых норм [8, с. 478].

Но если рассматривать международные договоры, которые зачастую охватывают предмет публичного права (договоры о сотрудничестве, о правовой помощи, о правах и свободах человека и гражданина и др.) предметно, то они несомненно выступают в качестве источников права.

В России порядок заключения международных договоров РФ, иные вопросы статуса международных договоров регулируются в Законе РФ от 15 июля 1995 г. «О международных договорах Российской Федерации», в ином законодательстве, международном праве, а также Федеральным законом от 4 января 1999 г. № 4-Ф3 предусмотрено заключение международных соглашений в сфере внешних связей субъектами РФ от своего имени.

Но если место международных договоров в системе источников отечественного права определено, то этого нельзя сказать о внутригосударственных договорах.

Начиная с подписания Федеративного договора от 31 марта 1992 г., который сыграл ключевую роль в сохранении и упорядочении единства России как федерации, широкое распространение получили вертикальные внутригосударственные договоры, которые были направлены на расширение и уточнение разграничения предметов ведения и полномочий в пределах совместного ведения Российской Федерации и ее субъектов [2, с. 71].

При этом практика внутригосударственных договоров в РФ опережает законодательство о процедуре их заключения. Встречаются следующие виды договоров и соглашений:

а) договор субъекта РФ с Российской Федерацией о разграничении полномочий между органами государственной власти и органами государственной власти субъектов (ч. 3 ст. 11 Конституции РФ 1993 г.; ст. 26.7 Федерального закона от 6 октября 1999 г. № 184-Ф3);

б) соглашения между федеральными органами исполнительной власти и исполнительными органами государственной власти субъектов о передаче друг другу осуществ- ления части своих полномочий (пп. 2-3 ст. 78 Конституции РФ 1993 г.);

в) договоры между органами государственной власти субъектов и органами местного самоуправления о передаче органам местного самоуправления осуществления отдельных государственных полномочий.

Еще двумя видами договоров и соглашений с участием субъектов, регулирующими отношения по горизонтали, являются:

г) договоры между органами государственной власти автономного округа, входящего в состав области (края), и, соответственно, органами государственной власти края или области в сложноустроенных субъектах (п. 4 ст. 66 Конституции РФ 1993 г.);

д) договоры «о дружбе и сотрудничестве» по горизонтали отношений - между субъектами Российской Федерации.

Принципы и порядок заключения вертикальных договоров и соглашений регулируются федеральной Конституцией и федеральным законодательством. Первым таким федеральным законом является Федеральный закон от 24 июля 1999 г. № 119-Ф3, который утратил свое действие, а пришедший на смену 4 июля 2003 г. Федеральный закон № 95-Ф3 усложнил принципы и процедуру заключения внутригосударственных договоров, тем самым воздействовав на сокращение практики такого рода договоров (ст. 26.7 № 95-Ф3). При этом нет законодательного определения внутригосударственного договора, а также нет четкости в определении отношения этих договоров к другим нормативным актам в системе источников права.

\section{Договоры как источники публичного права}

Однако, несмотря на вышеуказанное воздействие закона на договорные отношения, нормативные договоры обладают всеми признаками для выделения их в качестве самостоятельного источника публичного права.

Нормативный договор - это договор, устанавливающий правовые нормы или их нормативные интерпретации, а индивидуальный договор - договор, создающий индивидуальные правовые установления или их правообязательные интерпретации [3, с. 41]. 
Также следует отметить, что преимуществом договора как источника публичного права перед другими источниками является природа его создания, а именно волеизъявление и добровольность при его заключении, что не свойственно иным односторонним актам публичной власти. Эта особенность явно прослеживается при раскрытии определения нормы права. В современной юридической литературе под нормой права принято понимать формально-определенное правило поведения, установленное и обеспеченное обществом и государством, закрепленное и опубликованное в официальных актах, направленное на регулирование общественных отношений путем определения прав и обязанностей участников [10, с. 168$]$.

\section{Вывод}

Исходя из сказанного, можно сделать вывод, что законодатель стремится минимизировать практику заключения договоров в публичном праве по понятным нам причинам, однако необходимо выработать универсальное определение нормативного договора, в достаточной мере проработать как теорию договора, так и теорию правового акта в целом, а также издать закон о нормативных правовых актах, в который будут включены соответствующие положения.

\section{СПИСОК ЛИТЕРАТУРЫ}

1. Авакьян, С. А. Конституционное право России : в 2 т. / С. А. Авакьян. - 6-е изд., перераб. и доп. - М. : Норма, 2014.

2. Артемова, С. Ю. Классификация юридических коллизии иерархического вида / С. Ю. Артемова // Вестник Волгоградского государственного университета. Серия 5, Юриспруденция. - 2015. № 2. - C. 71.

3. Иванов, В. В. Нормативный конституционно-правовой договор: теория и практика. К критике современной теории государства / В. В. Иванов. М. : Территория будущего, 2008. - 352 с.

4. Карева, И. А. Нормативные акты в системе источников правил правотворческой техники / И. А. Карева // Вестник Волгоградского государственного университета. Серия 5, Юриспруденция. -2014 . - № 3. - С. $80-82$.

5. Кулакова, Ю. Ю. Место нормативно-правового договора в системе форм права / Ю. Ю. Кула- кова // История государства и права. - 2007. - № 8. C. 5-7.

6. Морозова, Л. А. Теория государства и права / Л. А. Морозова. - 5-е изд., перераб. и доп. -М. : Норма : ИНФРА-М, 2014. - 464 c.

7. Нечитайло, М. А. Нормативный договор как источник права : автореф. дис. ... канд. юрид. наук / Нечитайло Марина Анатольевна. - М., 2002. - 188 с.

8. Общепризнанные принципы и нормы международного права, международные договоры в практике конституционного правосудия : материалы Всерос. совещ. / М. А. Митюкова [и др.]. - М. : Международные отношения, 2004. - 536 c.

9. Определение Конституционного суда Российской Федерации от 2 июля 2013 г. № 1055-О. Доступ из справ.-правовой системы «КонсультантПлюс».

10. Перевалов, В. Д. Теория государства и права / В. Д. Перевалов. - 4-е изд., перераб. и доп. - М. : Норма : ИНФРА-М, 2016. - 496 c.

11. Российская Федерация. Конституция (1993). Конституция Российской Федерации : офиц. текст. М. : Маркетинг, 2001. - 39

12. Тихомиров, Ю. А. Правовые акты : учеб.практ. и справ. пособие / Ю. А. Тихомиров, И. В. Котелевская. - М. : Юринформцентр, 1999. - 381 с.

13. Тихомиров, Ю. А. Публичное право / Ю. А. Тихомиров. - М. : БЕК, 1995. - 496 с.

14. Федеральный закон «О международных договорах Российской Федерации» от 15 июля 1995 г. № 101-Ф3 : (по состоянию на 12 марта 2014 г.). Доступ из справ.-правовой системы «КонсультантПлюс».

15. Федеральный закон «О принципах и порядке разграничения предметов ведения и полномочий между Российской Федерацией и субъектами Российской Федерации» от 24 июня 1999 г. : (по состоянию на 24 июня 1999 г.). - Доступ из справ.правовой системы «КонсультантПлюс».

16. Федеральный закон «Об общих принципах организации законодательных (представительных) и исполнительных органов государственной власти субъектов Российской Федерации» от 06 октября 1999 г. : (по состоянию на 07 июня 2017 г.). - Доступ из справ.-правовой системы «КонсультантПлюс».

\section{REFERENCES}

1. Avakyan S.A. Konstitutsionnoe pravo Rossii: $v 2$ t. [The Constitutional Law of Russia: in 2 vols.]. Moscow, Norma Publ., 2014.

2. Artemova S.Yu. Klassifikatsiya yuridicheskikh kollizii ierarkhicheskogo vida [Classification of Legal Collisions of a Hierarchical Type]. Vestnik Volgogradskogo 


\section{ТЕОРИЯ И ПРАКТИКА ГОСУДАРСТВЕННО-ПРАВОВОГО РАЗВИТИЯ}

gosudarstvennogo universiteta. Seriya 5, Yurisprudentsiya [Science Journal of Volgograd State University. Jurisprudence], 2015, no. 2, p. 71.

3. Ivanov V.V. Normativnyy konstitutsionnopravovoy dogovor: teoriya i praktika. K kritike sovremennoy teorii gosudarstva [Normative Constitutional-Legal Treaty: Theory and Practice. To Criticism of the Modern Theory of the State]. Moscow, Territoriya budushchego Publ., 2008. 352 p.

4. Kareva I.A. Normativnye akty v sisteme istochnikov pravil pravotvorcheskoy tekhniki [Normative Acts in the System of Sources of Rules of Law-Making Technology]. Vestnik Volgogradskogo gosudarstvennogo universiteta. Seriya 5, Yurisprudentsiya [Science Journal of Volgograd State University. Jurisprudence], 2014, no. 3, pp. 80-82.

5. Kulakova Yu.Yu. Mesto normativno-pravovogo dogovora $v$ sisteme form prava [The Place of the Normative Legal Contract in the System of Forms of Law]. Istoriya gosudarstva i prava, 2007, no. 8, pp. 5-7.

6. Morozova L.A. Teoriya gosudarstva i prava [The Theory of State and Law]. Moscow, Norma Publ.; INFRA-M Publ., 2014. 464 p.

7. Nechitaylo M.A. Normativnyy dogovor kak istochnik prava: avtoref. dis. ... kand. yurid. nauk [Normative Treaty as a Source of Law. Cand. jurid. sci. abs. diss.]. Moscow, 2002. 188 p.

8. Mityukova M.A., et al., eds. Obshchepriznannye printsipy $i$ normy mezhdunarodnogo prava, mezhdunarodnye dogovory v praktike konstitutsionnogo pravosudiya: materialy Vseros. soveshch [Common Principles and Norms of International Law, International Treaties in the Practice of Constitutional Justice: Materials of the All-Russian Meeting]. Moscow, Mezhdunarodnye otnosheniya, 2004. 536 p.

9. Opredelenie Konstitutsionnogo suda Rossiyskoy Federatsii ot 2 iyulya 2013 g. № 1055-O [Decision of the Constitutional Court of the Russian Federation of July 2, 2013 no. 1055-O]. Access from Reference Legal System "KonsultantPlyus".
10. Perevalov V.D. Teoriya gosudarstva i prava [The Theory of State and Law]. Moscow, Norma Publ.; INFRA-M Publ., 2016. 496 p.

11. Konstitutsiya Rossiyskoy Federatsii: ofits. tekst. 1993 [The Constitution of the Russian Federation: Official Text. 1993]. Moscow, Marketing Publ., 2001.39 p.

12. Tikhomirov Yu.A., Kotelevskaya I.V. Pravovye akty: ucheb.-prakt. i sprav. posobie [Legal Acts: A Training Manual and Reference Manual]. Moscow, Yurinformtsentr Publ., 1999. 381 p.

13. Tikhomirov Yu.A. Publichnoe pravo [The Public Law]. Moscow, BEK Publ., 1995. 496 p.

14. Federalnyy zakon «O mezhdunarodnykh dogovorakh Rossiyskoy Federatsii» ot 15 iyulya 1995 g. № 101-FZ (po sostoyaniyu na 12 marta 2014 g.) [Federal Law “On International Treaties of the Russian Federation” of July 15, 1995 no. 101-FL (as of March 12, 2014)]. Access from Reference Legal System "KonsultantPlyus".

15. Federalnyy zakon «O printsipakh i poryadke razgranicheniya predmetov vedeniya $i$ polnomochiy mezhdu Rossiyskoy Federatsiey i subyektami Rossiyskoy Federatsii» ot 24 iyunya 1999 g. (po sostoyaniyu na 24 iyunya 1999 g.) [Federal Law “On the Principles and Procedure for the Delineation of Subjects of Reference and Authorities between the Russian Federation and the Subjects of the Russian Federation" of June 24, 1999 (as of June 24, 1999)]. Access from Reference Legal System "KonsultantPlyus".

16. Federalnyy zakon «Ob obshchikh printsipakh organizatsii zakonodatelnykh (predstavitelnykh) $i$ ispolnitelnykh organov gosudarstvennoy vlasti subyektov Rossiyskoy Federatsii» ot 06 oktyabrya 1999 g. (po sostoyaniyu na 07 iyunya 2017 g.) [The Federal Law "On General Principles for the Organization of Legislative (Representative) and Executive Bodies of State Power of the Subjects of the Russian Federation" of October 6, 1999 (as of June 7, 2017)]. Access from Reference Legal System "KonsultantPlyus".

\section{Information about the Author}

Egor V. Krivosheev, Postgraduate Student, Department of Constitutional Law, Ural State Legal University, Kolmogorova St., 54, 620034 Ekaterinburg, Russian Federation, ekrivosheev@yandex.ru.

\section{Информация об авторе}

Егор Вячеславович Кривошеев, аспирант кафедры конституционного права, Уральский государственный юридический университет, ул. Колмогорова, 54, 620034 г. Екатеринбург, Российская Федерация, ekrivosheev@yandex.ru. 